See discussions, stats, and author profiles for this publication at: https://www.researchgate.net/publication/7101349

\title{
The role of antifibrinolytic agents in gynecologic cancer surgery
}

Article in Saudi medical journal · May 2006

Source: PubMed

6 authors, including:

Nalan Celebi

Hacettepe University

44 PUBLICATIONS 279 CITATIONS

SEE PROFILE

Ozgur Canbay

40 PUBLICATIONS 483 CITATIONS

SEE PROFILE

Some of the authors of this publication are also working on these related projects:
Mehtap Selçuk

Acıbadem Mehmet Ali Aydınlar Üniversitesi

4 PUBlications 39 Citations

SEE PROFILE

Ayşe Heves Karagöz

Hacettepe University

35 PUBLICATIONS 397 CITATIONS

SEE PROFILE

Esmolol View project 


\title{
The role of antifibrinolytic agents in gynecologic cancer surgery
}

\author{
Nalan Celebi, MD, Bilge Celebioglu, MD, Mehtap Selcuk, MD, Ozgur Canbay, MD, \\ Ayse H. Karagoz, MD, Ulku Aypar, MD.
}

ABSTRACT

\begin{abstract}
Objective: To compare the effects of crystalloid and colloid solutions, tranexamic acid and epsilon-aminocaproic acid on the need for allogenic blood transfusion and on coagulation and fibrinolysis parameters.

Methods: We conducted the study in the Anesthesiology and Reanimation Department of Hacettepe University Medical Faculty, Ankara, Turkey between March 2004 and April 2005. The study included 105 patients, classified by the American Society of Anesthesiology as physical status groups I-II, undergoing gynecologic cancer treatment. We divided them into 5 groups: group I (crystalloid) received crystalloid solutions, group II (colloid) received colloid solutions, group III (tranexamic acid) received $10 \mathrm{mg} \cdot \mathrm{kg}^{-1}$ tranexamic acid, and group 5 (epsilon-aminocaproic acid) received $100 \mathrm{mg} \cdot \mathrm{kg}^{-1}$ epsilonaminocaproic acid. All patients' bleeding amount was measured and recorded perioperatively, and at the 12th and
\end{abstract}

24th hours postoperatively. We then evaluated the patients' hemoglobin, hematocrit, activated thromboplastin time, international normalized ration, fibrinogen, and thrombocyte count and symptoms of pulmonary embolism.

Results: In comparing the amount of bleeding, the bleeding in the tranexamic acid group was $30.8 \%$ less than the crystalloid group $(p<0.05), 33.3 \%$ less than the colloid group $(p<0.05)$, and $23.9 \%$ less than the epsilonaminocaproic acid group $(p<0.05)$.

Conclusion: When the negative effects of blood transfusions were considered, tranexamic acid administration can be recommended for decreasing the need for blood transfusion in gynecologic cancer surgery.

Saudi Med J 2006; Vol. 27 (5): 637-641
$I^{n}$ radical surgical procedures for gynecologic malignancy, a large amount of blood loss can be seen and this blood loss can make allogenic blood transfusion necessary. Blood transfusions are known to increase complications and morbidity. ${ }^{1}$

The purpose of this study was to compare the effects of crystalloid and colloid solutions, tranexamic acid and epsilon-aminocaproic acid on the need for allogenic blood transfusion and on coagulation and fibrinolysis parameters.

Hypovolemia is frequently encountered in surgery, trauma and intensive care unit patients. During surgery, there is often an absolute or relative decrease in blood volume. In radical surgical procedures for gynecologic malignancies, there is a significant amount of blood loss. Although it is widely accepted that it is important to replace fluids sufficiently, discussions continue regarding the optimal strategy. ${ }^{2}$ The strategies can be considered to be between crystalloid and colloid use and blood product transfusions. In procedures in which more than a liter of blood loss is anticipated, we are prepared with the use of acute normovolemic hemodilution and cheap blood conservation strategies. ${ }^{2,3}$ In a patient 
which has been hemodiluted the red blood cell loss decreases as during the surgical procedure the blood that is lost decreases the hematocrit. ${ }^{3}$ Use of crystalloid and colloid solutions can sometimes result with coagulation system changes, deposition, itching, anaphylactic reactions and decrease in renal function. ${ }^{4,5}$ Acute normovolemic hemodilution and decrease in the hematocrit does not cause problems in high risk patients like coronary heart disease, severe valvular disease and chronic renal disease as compensatory mechanisms guarantee tissue oxygenation and systemic oxygen transport. ${ }^{6,7}$ However, in patients with severe anemia or coagulation disorders a need for blood and blood products may occur.

Methods. After obtaining permission from the local ethics committee and informed patient consents, 105 patients between the ages of 20-60 years old in American Society of Anesthesiology (ASA) physical status groups I-II, cervix cancer stage I or II, scheduled for type III hysterectomy (total abdominal hysterectomy and bilateral salpingo oophorectomy and bilateral para aortic and pelvic lymphadenectomy) were included in the study. A double blind, randomized and prospective study was carried out and the patients were randomly divided into 4 groups. Patients with cardiac, endocrine or renal diseases and those with coagulopathy and medication allergies, and patients who needed blood transfusion during surgery were excluded from the study. The patients' demographic characteristics are shown in Table 1. For fluid replacement, crystalloid solutions $(0.9 \% \mathrm{NaCl}$, Ringers Lactate, Isolyte-S) were given to group I $(n=26)$, colloid solutions (Isohes, Hemaccel, HAES) to group II $(\mathrm{n}=26)$, crystalloid solutions and $10 \mathrm{mg} . \mathrm{kg}^{-}$ ${ }^{1}$ tranexamic acid to group III $(\mathrm{n}=27)$, and crystalloid solutions and $100 \mathrm{mg} \cdot \mathrm{kg}^{-1}$ epsilon-aminocaproic acid to group IV $(n=26)$. Considering the patients' weight perioperative fluid therapy was managed in order to replace maintenance requirements, preexisting fluid deficits caused by preoperative fasting, surgical wound losses including blood loss. ${ }^{8}$ After patients were taken to the operating room they were placed on ECG monitoring, $\mathrm{SpO}_{2}$ saturation, and non-invasive blood pressure monitoring before induction. For induction of anesthesia 1-3 mg. $\mathrm{kg}^{-1}$ propofol and $0.08 \mathrm{mg} \cdot \mathrm{kg}^{-1}$ vecuronium bromide were used in all groups. Following $20 \mu \mathrm{g} \mathrm{kg}^{-1}$ alfentanil endotracheal intubation was performed. After induction and before the surgical incision, group III patients were given tranexamic acid and group IV patients were given epsilon-aminocaproic acid. Anesthesia was maintained with $70 \% \mathrm{~N}_{2} \mathrm{O}, 30 \% \mathrm{O}_{2}, 2 \%$ sevoflurane and vecuronium bromide when necessary. Before beginning the surgical procedure a central venous catheter was placed, and central venous pressure, invasive blood pressure and urine output were monitored.

Blood loss was recorded intraoperatively and at the 12th and 24th hours postoperatively in all groups. The lost blood was estimated by calculating the blood in suction plus sponge counting plus the blood drained in postoperative 24 hours. All patients' preoperative and 12th and 24th hour postoperative hemoglobin, hematocrit, activated thromboplastin time (aPTT), international normalized ration (INR), fibrinogen, thrombocyte count and symptoms of pulmonary embolism were evaluated preoperatively and 12th and 24th hour postoperatively in all groups. It was planned that any patient with clinical symptoms of pulmonary embolism (with symptoms such as, dyspnea, hemoptysis, pleuritic chest pain, apprehension, cough in addition to tachypnea, rales, elevated $p$ in electrocardiography, tachycardia, fever) would be evaluated with pulmonary scintigraphy.

One-way analysis of variance, Duncan test and Krusskal-Wallis variance analysis were used to compare the variables in the 4 groups. Time related variables were analyzed using paired t-test and Wilcoxon test. The differences in variables related to time and coagulation values were analyzed with Chi-square and Kappa tests. A $p<0.05$ was accepted as statistically significant.

Results. There were no significant differences in demographic data between groups (Table 1). The Hct, total blood loss, mean arterial pressure (MAP), central venous pressure (CVP), peripheral oxygen saturation $\left(\mathrm{SaO}_{2}\right)$ are shown in Table 2. No significant changes were found between or within groups with respect to MAP, CVP, $\mathrm{SaO}_{2}$, and ascites. Thrombocytes (Plt), fibrinogen, aPTT and INR values are shown on Table 3.

Table 1 - Demographic data (mean \pm SD).

\begin{tabular}{|lcccc|}
\hline Variants & $\begin{array}{c}\text { Group I } \\
(\mathbf{N = 2 6})\end{array}$ & $\begin{array}{c}\text { Group II } \\
(\mathbf{N = 2 6})\end{array}$ & $\begin{array}{c}\text { Group III } \\
(\mathbf{N = 2 7})\end{array}$ & $\begin{array}{c}\text { Group IV } \\
(\mathbf{N = 2 6})\end{array}$ \\
\hline Age (year) & $39.2 \pm 8.8$ & $40 \pm 7.2$ & $42 \pm 6.8$ & $43 \pm 7.2$ \\
Weight (kg) & $65 \pm 3$ & $66 \pm 4$ & $67 \pm 4$ & $64 \pm 2$ \\
Height (cm) & $158 \pm 7$ & $160 \pm 9$ & $157 \pm 9$ & $162 \pm 5$ \\
$\begin{array}{l}\text { Duration of surgery } \\
\text { (minutes) }\end{array}$ & $57 \pm 9$ & $51 \pm 13$ & $60 \pm 11$ & $51 \pm 9$ \\
\hline
\end{tabular}


Antifibrinolytics in cancer surgery ... Celebi et al

Table 2 - Research groups' Hgb, Hct, Blood loss, mean arterial pressure, peripheral oxygen saturation and central venous pressure values (mean \pm $\mathrm{SD})$.

\begin{tabular}{|c|c|c|c|c|c|c|c|c|}
\hline \multirow{2}{*}{$\begin{array}{l}\text { Parameters } \\
\mathrm{Hb}_{0}(\mathrm{~g} / \mathrm{dl})\end{array}$} & \multicolumn{2}{|c|}{ Group I (N=26) } & \multicolumn{2}{|c|}{ Group II (N=26) } & \multicolumn{2}{|c|}{ Group III (N=27) } & \multicolumn{2}{|c|}{ Group IV (N=26) } \\
\hline & $12.7 \pm 0.3$ & & $11.6 \pm 1.1$ & & $12.11 \pm 0.7$ & & $12.08 \pm 0.4$ & \\
\hline $\mathrm{Hb}_{1}(\mathrm{~g} / \mathrm{dl})$ & $11.2 \pm 0.5$ & $(\mathrm{p}=0.023)$ & $9.9 \pm 1.7$ & $(p=0.003)$ & $10.29 \pm 1.6$ & $(p=0.023)$ & $9.8 \pm 0.6$ & $(p=0.007)$ \\
\hline $\mathrm{Hb}_{2}(\mathrm{~g} / \mathrm{dl})$ & $11 \pm 0.3$ & $(p=0.023)$ & $7.8 \pm 1.2$ & $(p=0.003)$ & $10.32 \pm 0.4$ & $(p=0.025)$ & $9.6 \pm 0.2$ & $(p=0.003)$ \\
\hline $\mathrm{Hct}_{0}(\%)$ & $36.21 \pm 1.3$ & & $31.28 \pm 2.1$ & & $35.28 \pm 1.8$ & & $36.02 \pm 2.1$ & \\
\hline $\mathrm{Hct}_{1}(\%)$ & $32.32 \pm 1.8$ & $(p=0.007)$ & $29.38 \pm 1.8$ & $(p=0.025)$ & $30.01 \pm 2.1$ & $(p=0.003)$ & $30.92 \pm 2.2$ & $(p=0.001)$ \\
\hline $\mathrm{Hct}_{2}(\%)$ & $32.28 \pm 1.1$ & $(p=0.002)$ & $29.55 \pm 1.2$ & $(p=0.025)$ & $30.14 \pm 2.2$ & $(p=0.007)$ & $29.30 \pm 2.2$ & $(p=0.000)$ \\
\hline Total blood loss (cc) & $405 \pm 40$ & & $390 \pm 35$ & & $270 \pm 40$ & $(p=0.005)$ & $355 \pm 40$ & \\
\hline CVP (mm Hg) & $4 \pm 1$ & & $5 \pm 0.8$ & & $5 \pm 1.1$ & & $4 \pm 1.2$ & \\
\hline MAP (mm Hg) & $91 \pm 15$ & & $92 \pm 15$ & & $95 \pm 15$ & & $96 \pm 15$ & \\
\hline $\mathrm{SaO}_{2}(\%)$ & $98 \pm 2$ & & $98 \pm 1$ & & $98 \pm 2$ & & $98 \pm 2$ & \\
\hline $\begin{array}{r}\text { Group } 1 \text { - crys } \\
\mathrm{Hb}_{\mathrm{o}}- \\
\mathrm{Hct}_{1}-\end{array}$ & $\begin{array}{l}\text { loid group, } \\
\text { ginning hen } \\
\text { h hour hem }\end{array}$ & $\begin{array}{l}\text { up II - coll } \\
\text { lobin, } \mathrm{Hb}_{1} \\
\text { rit, } \mathrm{Htc}_{2}-\end{array}$ & $\begin{array}{l}\text { roup, group } \\
\text { h hour hemo } \\
\text { hour hemato } \\
\mathrm{SaO}_{2} \text { - peri }\end{array}$ & $\begin{array}{l}\text { - tranexam } \\
\text { bin, } \mathrm{Hb}_{2}-2 \\
\text {, CVP - cen } \\
\text { eral oxygen }\end{array}$ & $\begin{array}{l}\text { group, grou } \\
\text { our hemoglo } \\
\text { enous pressu } \\
\text { ation }\end{array}$ & $\begin{array}{l}\text { IV - epsilo } \\
\text { n Hct - be } \\
\text { MAP - m }\end{array}$ & $\begin{array}{l}\text { inocaproic a } \\
\text { ng hematocr } \\
\text { arterial press }\end{array}$ & group, \\
\hline
\end{tabular}

Table 3 - Research groups' thrombocyte, fibrinogen, aPTT and international normalized ration (INR) values (mean \pm SD).

\begin{tabular}{|c|c|c|c|c|c|c|c|c|}
\hline Parameters & \multicolumn{2}{|c|}{ Group I (N=26) } & \multicolumn{2}{|c|}{ Group II (N=26) } & \multicolumn{2}{|c|}{ Group III (N=27) } & \multicolumn{2}{|c|}{ Group IV (N=26) } \\
\hline $\mathrm{Plt}_{0}\left(\times 10^{3} / \mathrm{uL}\right)$ & \multicolumn{2}{|l|}{$319.36 \pm 42$} & \multicolumn{2}{|l|}{$284.72 \pm 44$} & \multicolumn{2}{|l|}{$284.3 \pm 38$} & \multicolumn{2}{|l|}{$278.4 \pm 48$} \\
\hline $\mathrm{Plt}_{1}\left(\times 10^{3} / \mathrm{uL}\right)$ & \multicolumn{2}{|l|}{$284.25 \pm 38$} & \multicolumn{2}{|l|}{$250.60 \pm 37$} & \multicolumn{2}{|l|}{$273.42 \pm 35$} & \multicolumn{2}{|l|}{$260.72 \pm 35$} \\
\hline $\mathrm{Plt}_{2}\left(\times 10^{3} / \mathrm{uL}\right)$ & \multicolumn{2}{|l|}{$264.46 \pm 34$} & \multicolumn{2}{|l|}{$245.60 \pm 30$} & $257.63 \pm 34$ & & \multicolumn{2}{|l|}{$249.3 \pm 38$} \\
\hline Fibrinogen $_{0}(\mathrm{mg} / \mathrm{dl})$ & \multicolumn{2}{|l|}{$393.29 \pm 42$} & \multicolumn{2}{|l|}{$345.92 \pm 65$} & $360.89 \pm 44$ & & \multicolumn{2}{|l|}{$380.04 \pm 54$} \\
\hline Fibrinogen $_{1}(\mathrm{mg} / \mathrm{dl})$ & $478.74 \pm 37$ & $(p=0.023)$ & $437.08 \pm 42$ & $(p=0.007)$ & $463.15 \pm 52$ & $(p=0.001)$ & $492.01 \pm 58$ & $(p=0.000)$ \\
\hline Fibrinogen $_{2}(\mathrm{mg} / \mathrm{dl})$ & $475.83 \pm 34$ & $(p=0.025)$ & $454.52 \pm 65$ & $(p=0.000)$ & $459.37 \pm 38$ & $(p=0.003)$ & $440.42 \pm 48$ & $(p=0.015)$ \\
\hline $\operatorname{aPTT}_{0}(\mathrm{sec})$ & \multicolumn{2}{|l|}{$45.65 \pm 8.4$} & $47.19 \pm 7$ & & $45.57 \pm 5$ & & \multicolumn{2}{|l|}{$44.38 \pm 4.5$} \\
\hline $\mathrm{aPTT}_{1}(\mathrm{sec})$ & $73.67 \pm 6.8$ & $(p=0.001)$ & $61.82 \pm 4.5$ & $(p=0.007)$ & $47.41 \pm 4.6$ & & $43.24 \pm 5.2$ & $(p=0.045)$ \\
\hline $\mathrm{aPTT}_{2}(\mathrm{sec})$ & \multicolumn{2}{|l|}{$38.39 \pm 9.8$} & \multicolumn{2}{|l|}{$40.19 \pm 4.6$} & $52.51 \pm 4.2$ & & \multicolumn{2}{|l|}{$48.72 \pm 3.9$} \\
\hline $\mathrm{INR}_{0}$ & \multicolumn{2}{|l|}{$1.93 \pm 0.04$} & \multicolumn{2}{|l|}{$1.39 \pm 0.03$} & \multicolumn{2}{|l|}{$1.19 \pm 0.03$} & \multicolumn{2}{|l|}{$1.24 \pm 0.03$} \\
\hline $\mathrm{INR}_{1}$ & \multicolumn{2}{|c|}{$3.33 \pm 0.02 \quad(p=0.023)$} & \multicolumn{2}{|c|}{$2.16 \pm 0.04(p=0.025)$} & \multicolumn{2}{|l|}{$1.35 \pm 0.02$} & \multicolumn{2}{|c|}{$1.44 \pm 0.02 \quad(p=0.037)$} \\
\hline $\mathrm{INR}_{2}$ & \multicolumn{2}{|c|}{$1.88 \pm 0.04$} & \multicolumn{2}{|c|}{$1.35 \pm 0.03$} & $1.31 \pm 0.04$ & & \multicolumn{2}{|l|}{$1.38 \pm 0.04$} \\
\hline \multicolumn{9}{|c|}{$\begin{array}{l}\qquad p<0.05 \text { (according to beginning values) } \\
\quad \# p<0.05 \text { (according to beginning and 24th hour values) } \\
\text { ombocyte count, Plt }-12 \text { th hour thrombocyte count; } \text { Plt }_{2}-24 \text { th hour thrombocyte count, } \\
\text { gen }_{1}-12 \text { th hour value, fibrinogen } \\
\text { e }_{2}-24 \text { th hour value, } \text { aPTT }_{\mathrm{o}} \text { - beginning active partial thromboplastic time } \\
\text { e } \text { aPTT }_{2}-24 \text { th hour value, } \text { INR }_{\mathrm{o}} \text { - beginning value, } \mathrm{INR}_{1}-12 \text { th hour value, } \mathrm{INR}_{2}-24 \text { th hour value. }\end{array}$} \\
\hline
\end{tabular}


No significant difference was found between groups in $\mathrm{Hct}, \mathrm{Hb}$, thrombocyte count and mean fibrinogen $\mathrm{t}_{0}$ (starting time), $\mathrm{t}_{1}$ (value at 12 th hour) and $\mathrm{t}_{2}$ (24th hour value) values. No significant difference was found between crystalloid group, colloid group and epsilon-aminocaproic acid group with respect to total blood loss $(p>0.05)$; however, the total blood loss in tranexamic acid group was significantly less than the other groups $(p<0.05)$. An examination of the $\mathrm{t}_{0}, \mathrm{t}_{1}$ and $\mathrm{t}_{2}$ mean aPTT and INR values showed that there was a significant difference in $\mathrm{t}_{1}$ value between crystalloid group and the other groups $(p<0.05)$.

Discussion. The percentage of blood transfusions given in gynecologic procedures has been reported between $1.3 \%$ and $2.6 \% .^{9,10}$ There are some risks associated with blood transfusion such as hemolytic reactions, allergy, anaphylaxis, transfusion related acute pulmonary damage and infection transmission. In addition to discussion on the effect of intraoperative blood transfusion in oncologic surgery on the recurrence of cancer, work continues to decrease the need for intraoperative blood transfusion. ${ }^{11}$

In dealing with problems of prolonged intravascular homeostasis, an alternative method for decreasing blood loss is the use of some medications. Tranexamic acid shows antifibrinolytic effect by blocking the lysine-binding sites of plasminogen and plasmin molecules and in that way prevents attachment of plasminogen and plasmin to the fibrin substrata. In addition, tranexamic acid inhibits the conversion of plasminogen to plasmin by plasminogen activators. ${ }^{12}$ Aprotinin and epsilon-aminocaproic acid has been shown to decrease blood loss in major surgical procedures. ${ }^{13-15}$ However, aprotinin is an expensive medication and can cause anaphylaxis. In vitro epsilon-aminocaproic acid attaches to the lysinebinding sites of the plasminogen molecule causing a change in the conformation of plasminogen. Its major in vivo effects are antifibrinolytic and in high concentrations, it inhibits plasmin and plasminogen activation. ${ }^{16}$ On the other hand, tranexamic acid in vitro is 10 times more potent than aminocaproic acid. In addition, epsilon-aminocaproic acid has been reported to cause obstructive uropathy, thrombosis in glomerular capillaries, rhabdomyolysis and myoglobulinuria. ${ }^{15}$

The pre incisional use of tranexamic acid has been reported to decrease bleeding in cardiopulmonary bypass surgery, total hip arthroplasty, total knee arthroplasty and cesarean operations..$^{13,17-19}$ However, when it is given intraoperatively it does not decrease bleeding. ${ }^{20}$ In our study, in comparing the tranexamic acid group with the crystalloid group the percentage of bleeding was $33.3 \%$ less, and in comparison with the colloid group it was $30.8 \%$ less. In comparison with the epsilon-aminocaproic acid group, however, a $23.9 \%$ decrease was seen. This decrease in blood loss obtained in tranexamic acid group was statistically significant in comparison with the other 3 groups.

Harley et $\mathrm{al}^{21}$ reported that epsilon-aminocaproic acid clearly decreased total bleeding amount in total hip arthroplasty compared to placebo. ${ }^{21}$ Kluger et $\mathrm{a}^{22}$ reported a decrease in chest tube drainage in coronary artery bypass surgery with the use of both pre incisional epsilon-aminocaproic acid and after heparinization. ${ }^{22}$ Florentino-Pineda et $\mathrm{al}^{23}$ also reported that epsilon-aminocaproic acid clearly decreased perioperative bleeding in patients with idiopathic scoliosis undergoing posterior surgery. ${ }^{23}$ There are, however, contrary findings in the literature. Amar et $\mathrm{al}^{24}$ reported that while there was a decrease in perioperative blood loss with the use of aprotinin and epsilon-aminocaproic acid in major orthopedic procedures in cancer patients, no clinical benefit was seen.

In comparing of epsilon-aminocaproic acid group with the crystalloid and colloid groups in our study, although there was a decrease of $14 \%$ and $9 \%$ in total bleeding amount, there was no significant difference between the groups. Chauhan et al, ${ }^{25}$ however, reported that epsilon-aminocaproic acid and tranexamic acid clearly and equally effectively decreased bleeding in pediatric cardiac surgery. ${ }^{25}$ This situation may be due to the relatively small number of patients in the groups and the minimal amount of bleeding seen in the groups. If the number of patients in the groups had been greater, a clearer decrease in blood loss may have been seen.

As cerebral, mesenteric, pulmonary and retinal thromboses have been reported, the hypercoagulability of tranexamic acid and epsilon-aminocaproic acid arouses concerns. ${ }^{26} \mathrm{We}$ did not observe any decrease in oxygen saturation during surgery for any of the groups. We also did not find any clinical findings that would make one suspect thrombosis in any of our patients.

There was a clear decrease in blood loss with the pre incisional use of tranexamic acid in gynecological cancer surgery in our study compared to acute normovolemic hemodilution method and epsilonaminocaproic acid. This situation that tranexamic acid decreases bleeding in gynecological cancer surgery supports the fact that it is more potent than epsilon-aminocaproic acid. No clinical finding of thromboembolism occurred in our study for either medication.

As a result, considering the negative effects of blood transfusions, we recommend that tranexamic 
acid can be used in gynecological cancer surgery to decrease the need for transfusion.

\section{References}

1. Heiss MM. Risk of allogeneic transfusions. Br J Anaesth 1998; 81: 16-19.

2. Miletin MS, Stewart TE, Norton PG. Influences on physicians' choices for intravenous colloids. Intensive Care Med 2002; 28: 917-924.

3. Goodnough LT, Despotis GJ, Merkel K, Monk TG. A randomized trial comparing acute normovolemic hemodilution and preoperative autologous blood donation in total hip arthroplasty. Transfusion 2000; 40: 1054-1057.

4. Ness PM, Bourke DL, Walsh PC. A randomized trial of perioperative hemodilution versus transfusion of preoperatively deposited autologous blood in elective surgery. Transfusion 1992; 32: 226-230.

5. Warren BB, Durieux ME. Hydroxyethylstarch: safe or not? Anesth Analg 1997; 84: 206-211.

6. Moran M, Kapsner C. Acute renal failure associated with elevated plasma oncotic pressure. N Engl J Med 1987; 317: 150-153.

7. Spahn DR, Leone BJ, Reves JG, Pasch T. Cardiovascular and coronary physiology of acute isovolemic hemodilution: a review of monooxygen-carrying and oxygen-carrying solutions. Anesth Analg 1994; 78: 1000-1021.

8. Morgan EG, Maged SM Jr, Murray MJ. Clinical Anesthesiology. 3rd ed. New York (NY); Mc Graw Hill Company, Inc.: 1996. p. 626-643.

9. Van der Linden P, Schmartz D, DeGroote F, Mathieu N, Willaert P, Rausin I, et al. Critical hemoglobin concentration in anesthetized dogs: comparison of two plasma substitutes. Br J Anaesth 1998; 81: 556-562.

10. Kamani AA, McMorland GH, Wadsworth LD. Utilization of red blood cell transfusion in an obstetric setting. Am J Obstet Gynecol 1988; 159: 1177-1181.

11. Klapholz H. Blood transfusion in contemporary obstetric practice. Obstet Gynecol 1990; 75: 940-943.

12. Vamvakas EC. Transfusion-associated cancer recurrence and postoperative infection: meta analysis of randomized, controlled clinical trials. Transfusion 1996; 36: 175-186.

13. Hoylaerts M, Lijnen HR, Collen D. Studies on the mechanism of the antifibrinolytic action of tranexamic acid. Biochim Biophys Acta 1981; 673: 75-85.

14. Shore-Lesserson L, Reich DL, Vela-Cantos F. Tranexamic acid reduces transfusions and mediastinal drainage in cardiac repeat surgery. Anesth Analg 1996; 83: 18-26.
15. Mongan PD, Brown RS, Thwaites BG. Tranexamic acid and aprotinin reduce postoperative bleeding transfusions during primary coronary revascularization. Anesth Analg 1998; 87: 258-265.

16. Eaton MP, Deeb GM. Aprotinin versus epsilon-aminocaproic acid for aortic surgery using deep hypothermic circulatory arrest. J Cardiothorac Vasc Anesth 1998; 12: 548-552.

17. Hiippala S, Strid L, Wennerstrand M, Arvela V, Mantyla $\mathrm{S}$, Ylinen J, et al. Tranexamic acid (Cyklokapron) reduces perioperative blood loss associated with total knee arthroplasty. Br J Anaesth 1995; 74: 534-537.

18. Ekback G, Axelsson K, Ryttberg L, Edlund B, Kjelberg J, Weckstrom J, et al. Tranexamic acid reduces blood loss in total hip replacement surgery. Anesth Anal 2000; 112: 122130.

19. Ming-ying G, Lian-Fang W, Qi-feng S, Karin T. Clinical observation of blood loss reduced by tranexamic acid during and after caesarian section: a multi-center, randomized trial. Eur J Obstet Gynecol Reprod Biol 2004; 112: 154-157.

20. Benoni G, Fredin H. Fibrinolytic inhibition with tranexamic acid reduces blood loss and blood transfusion after knee arthroplasty; a prospective, randomized, double-blind study of 86 patients. J Bone Joint Surg Br 1996; 78: 434-440.

21. Harley BJ, Beaupre LA, Jones CA, Cinats JG, Guenther CR. The effect of epsilon-aminocaproic acid on blood loss in patients who undergo primary total hip replacement: a pilot study. Can J Surg 2002; 45: 185-190.

22. Kluger R, Olive DJ, Stewart AB, Blyth CM. Epsilonaminocaproic acid in coronary artery by-pass graft surgery: pre incision or postheparin? Anesthesiology 2003; 99: 12631269.

23. Florentino-Pineda I, Thompson GH, Poe-Kochert C, Huang RP, Haber LL, Blakemore LC. The effect of Amicar on perioperative blood loss in idiopathic scoliosis: the results of a prospective, randomized double-blind study. Spine 2004; 29: $233-238$

24. Amar D, Grant FM, Zhang H, Boland PJ, Leung DH, Healey JA. Antifibrinolytic therapy and perioperative blood loss in cancer patients undergoing major orthopedic surgery. Anesthesiology 2003; 98: 337-342.

25. Chauhan S, Das SN, Bisoi A, Kale S, Kiran U. Comparison of epsilon-aminocaproic acid and tranexamic acid in pediatric cardiac surgery. J Cardiothorac Vasc Anesth 2004; 18: 141143.

26. Reid RW, Zimmerman AA, Laussen PC, Mayer JE, Gorlin $\mathrm{JB}$, Burrows FA, et al. The efficacy of tranexamic acid versus placebo in decreasing blood loss in pediatric patients undergoing repeat cardiac surgery. Anesth Analg 1997; 84: 990-996. 